\title{
Žarko Paić
}

Uniwersytet w Zagrzebiu

zarko.paic@zg.t-com.hr

\section{Mi, s rubova Europe: Sumorni jezik i ,slavenska duša”}

\section{Gombrowicz ili o pobuni egzistencije}

Iskustvo moderne povijesti Europe može se nazvati praksom razaranja jezika kao forme duhovnoga bitka. Jezik posjeduje mističnu moć u višeznačnome kazivanju istine. Zbog toga se čak i u doba-bez-riječi određeno prelaskom u posthumano stanje digitalne slike osjeća potreba za uspostavom nove opće gramatike. Tko želi govoriti o duhovnome identitetu Europe u moderno doba, ne može zanijekati da se svijest o nužnosti destrukcije jezika pojavljuje drugim početkom ,naroda” izvan bilo kakve redukcije na mitske slike o veličini i žrtvi povijesti. Povijesna avangarda prve polovine 20. stoljeća bila je univerzalna forma preusmjeravanja povijesti iz bezuvjetnoga napretka u spirale budućnosti. Zagledana istodobno u iskon i ono nadolazeće, avangarda je otvarala nove perspektive duhovnoga razvitka. Posvuda se zbivalo ono „Isto” u razlikama: ruska avangarda i ukrajinska, poljska i talijanska, njemačka i francuska. Nisu više važne nacionalne razlike. Presudne su razlike u pristupu jeziku i slici onoga nadolazećega u suigri kaosa i forme. Jedan od pouzdanih svjedoka ovoga dugovjeka događanja u vlastitome labirintu znakova zacijelo je poljski književnik Witold Gombrowicz. Prethodnik egzistencijalnoga nemira epohe kraja individuuma u doba planetarne tehnike u romanu Ferdydurke napisanome 1937. godine govori o sukobu između stvaranja i razaranja forme. Jezik se ponajprije pojavljuje svezom ideje i kazivanja događaja s kojim nastaje susret. Dramatski susret nije, međutim, susret između Dvojega, subjekta i njegova dvojnika. Susret je to s licem Drugoga. U svojoj drugosti taj Drugi uvijek je uistinu netko Treći. 
No mjesto Trećega je prazno. Ono se ne nadomještava maskama božanskoga, čak i kada je jasno da travestija ljudske komedije precizno pokazuje granice smisla i besmisla ljudske egzistencije. Prva je pretpostavka ove praznine u nemogućnosti linearnoga kazivanja događanja. Sve se zbiva eruptivno, u spiralama i nenadanim obratima. Povijest na rubu europske duhovne avanture nikad ne može biti ,,velikom”. O veličini povijesti ne odlučuje karakter događaja. Presudno je ipak nešto drugo - koliko je, naime, povijest u svojoj jednokratnosti otvorenost duhovnoga lika Europe u njezinim bitnim mogućnostima filozofije, politike i religije. U najgorem slučaju, to je provincijalizam praćen osjećajem manje vrijednosti. Nema doista ni jednoga od „velikih” mislilaca i umjetnika 20. stoljeća koji se spram europskoga ruba ne odnosi kao spram zemljopisno-duhovne nelagode. Sjetimo li se samo Cioranovih pisama prijatelju filozofu Constantinu Noici, rumunjskome disidentu u doba totalitarnoga vođe Causescua, vidjet ćemo nešto dalekosežno. Gledajući iz druge perspektive onoga tko živi na granicama Carstva, Zapad se u ideji Europe pojavljuje slikom moralne dekadencije. Žrtvovati se za Europu znači biti poklonik njezinih ideja, a ne sljedbenik religioznoga kulta kapitalizma luksuza i potrošnje (Cioran 2011a: 147-156; 2011b: 157-165) ${ }^{1}$.

Ni današnji politički i kulturni maniheizam nije promijenio ovu istu staru ploču. Rascijep Europe na zapadnu i onu „drugu” koja se vjekovno određuje pojmovima ruba, periferije, provincije, a u modernome razdoblju znanstveno-tehničkoga napretka i političkoga liberalizma prostorom zakašnjele modernosti, izvorištem nazatka i duhom restauracije, iskustvom granice u odnosu spram Rusije kao carstva s drukčijom povijesnom misijom od europske, čini se kao da usudno određuje smisao kulture. Vjera u duhovne vrijednosti Europe ostaje nepomućenom čak i nakon žrtvovanja za izdane ideale prosvjetiteljstva. Ali, ono što ostaje upitnim predstavljaju ta uzvišena ,moralna načela". Što se skriva iza ovih velikih riječi? Kako je moguće razlučivati između onoga što se smatra duhovnim izvorima Europe i njezinim moralnim načelima? Zar su to dvije razdvojene sfere? Čini se da je raskol pitanje suvremenoga identiteta Europe. Od njegova prevladavanja ovisi budućnost održivosti same ideje. Mogućnosti drukčije Europe čine otuda njezinu duhovnu zbilju. Paul Valéry odredio je smisao izvora ideje Europe kroz tri duhovna lika. Kroz njih se oblikuje povijesnost naše civilizacije. To su:

${ }^{1}$ O pojmu kapitalizma kao religioznoga kulta piše Walter Benjamin (1991: 100-102). 
1) grčka filozofija s idejom uma i zajedničkoga boravišta ideje slobode (polis);

2) rimska politika s idejom univerzalnoga građanina bez obzira na etničko podrijetlo (res publica);

3) srednjovjekovno kršćanstvo s idejom onostranoga spasa duše kao cilja i smisla povijesnoga događanja (apokalipsa) (Valéry 2000: 405-414).

Tri izvora i sastavna dijela ideje Europe su mišljenje cjeline, praktična moć politike i pitanje spasa duše. Svaki govor o budućnosti Europe stoga ne može biti cjelovit bez filozofije, politike i religije. Ono što pokreće duhovno jedinstvo nije tiranija cjeline. Bez razlika nema skladnoga sklopa. Od samoga početka do kraja, ovo jedinstvo može biti smisleno samo ako se događa u iskustvu jezika. Tek s jezikom u njegovoj formi kazivanja slobode novoga početka može otpočeti govor o slobodi kao egzistenciji. No problem u samoodređenju političkoga osjećaja pripadnosti modernome svijetu liberalne demokracije u Istočnoj Europi već je od „proljeća naroda” 1848. godine bio u tome što je način shvaćanja ideje nacije-države bio problem kulture kao ideologije, a ne političke integracije razlika. Europa je za narode i kulture njezina ruba ostala do danas pitanjem „morala”. Ali ovo valja razumjeti u posve obrnutome smjeru od onoga o kojem je govorio Julien Benda. Njegov zagovor nadnacionalne Europe univerzalnosti prava i sloboda građanina proizlazi iz nužnosti svijesti o napretku slobode. Prosvjetiteljski mit o napretku uma suprotstavlja se svemu što pripada sferi „osjećaja”. Ako je um hladna razboritost prosuđivanja na temelju znanstvene istine o svijetu, tada se „logika srca”, o kojoj je govorio Blaise Pascal, mora suspendirati. U ime posljednjega cilja i smisla povijesti um ima prednost pred srcem. A to je sekularno carstvo istine povijesnoga ljudstva na putu prema vječnome stanju univerzalne mudrosti svijeta. Osjećaji su, dakle, prijetnja europskome poretku umno spoznate istine. Racionalnost politike ne potrebuje osjećaje. Štoviše, jezik osjećaja pripada poeziji kao temelju umjetnosti. Iz platonske perspektive ove europske dijalektike uma samo se znanost približava ideji univerzalnosti svijeta. Ne zaboravimo: Benda je za glavni jezik komunikacije buduće političke institucije federalne Europe odredio francuski jezik. Objašnjenje je, dakako, bilo tehničke naravi. Jer francuski jezik navodno savršeno zrcali duh racionalizma kakav se očekuje od nove nadnacionalne forme Europe (Benda 1933/1993; cf. 
Müller 2006: 125-137). Ako je put u pakao popločan dobrim namjerama, onda se iz ovoga može zaključiti da je lingvistički unitarizam Europe uvijek u znaku vladavine ,velike nacije”. Sve drugo čini se izlišnim u daljnjem objašnjenju.

Iskustvo jezika u kazivanju događaja susreta proizlazi iz slobode. Ako umjesto te ,patetične” riječi kao sinonima za ljudsko djelovanje stavimo u igru riječ egzistencija, tada smo suočeni s novom nelagodom. Sloboda kao egzistencija ne dolazi iz sfere Boga niti iz postojbine čovjeka. Ono odakle dolazi ono nenadano, ono što izaziva strah od lica Drugoga i njegove bezličnosti jest „nešto” samome jeziku neiskazivo i neizrecivo. Forma, naime, nikad ne može biti zgotovljena zauvijek. Ona ne posjeduje božanske osobine vječnosti, trajnosti, nepromjenljivosti. Gombrowicz egzistencijalnu avanturu događanja forme shvaća procesualno. Skinuti s prijestolja okamine lažne apstrakcije! Razračunati se s tradicijom u svim njezinim lažnim postignućima! Objaviti otvoreni rat samozadovoljnoj i samodovoljnoj opsesiji s kultom nacije! Forma se povijesno uspostavlja. Kada doseže vrhunac vlastite (ne)moći djelovanja u drugome okružju kulture, raspada se s najtežim posljedicama za „narod” i njegove kulturne relikvije. $\mathrm{S}$ formom nastaje kontingentni događaj. Ali taj se događaj ne zbiva negdje izvan samoga jezika, u tzv. objektivnome svijetu struktura i funkcija bezlične mašinerije povijesne dijalektike društvenih odnosa. $\mathrm{S}$ formom kao idejom stvaranja i razaranja događaja otpočinje mogućnost jedne nesvodljive egzistencije. Ona umjetnost ima za svoju pretpostavku. Ali to nipošto ne vrijedi u formalnome značenju autonomnoga života i njemu pripadnoga svijeta. U romanu Ferdydurke vrijeme stvaralačko-razaralačkoga događaja svijeta mjeri se jedino iskustvom slobode. Eksperimentiranje s jezikom slobodi podaruje njezin iskonski pra-temelj (an-arhé). Zahvaljujući tome još postoje platoi posljednjih teritorija nikad osvojene zemlje. I nije slučajno da već na počecima ovoga romana ideja pisac ukazuje na Dantea. To je iskustvo sumornoga lutanja životom na razmeđi između ushita i usahnuća vrijednosti, kada se više ništa ne pokazuje u svojoj čistoći i kada su obzorja istine zatamnjena: „Na pola puta mojega života, nađoh se u mračnoj šumi. A ova šuma, da bude gore, bješe zelena" (Gombrowicz 1981: 14)2.

${ }^{2} \mathrm{O}$ ideji ovoga romana i njegovim bitnim duhovnim aspektima vidi ogled Susan Sontag (2002). 
Može li se nešto spasonosno razviti iz ove duhovne situacije nalik parodiji jedne opće tragedije duhovnoga iskustva Europe kakvu su 1930-ih godina naviještali bitni mislioci naše epohe? Ponajprije, ostanemo li u okružju Gombrowiczeva radikalnoga razaranja svijeta kao forme (duha), jer forma još od Platona nije tek izvanjski lik ideje, već njezin unutarnji život u svim preobrazbama, tada primjećujemo da je pitanje jezika u ideji Europe od samoga početka ključno za razumijevanje egzistencije čovjeka. Nije to jezik apstraktne univerzalnosti znanosti, a niti, pak, jezik svakodnevnoga života u svojoj tehničkoj banalnosti ponavljanja rutinskih operacija. Možda se riječ u doba tehno-znanosti srozala do neupečatljive fraze. No neprijeporno je da jezikom imenujemo svijet. Kada se taj i takav svijet gubi u vizualnome kôdu informacije, od njega ipak preostaje trag smisla. U obzorju razumijevanja smisao treperi poput trske na vjetru. Ono što preostaje od jezika u njegovoj ogoljenosti od „biti” kazivanja jest otvorenost duhovnoga svijeta. Binarne opreke svetoga i svjetovnoga zamijenjene su već u industrijskome razdoblju 19. stoljeća oprekama uzvišenoga i banalnoga. Proces zamjene ne odigrava se ipak samo u estetskome smislu. To isto pogađa političko u moderno doba. Najbolje je to odredio Carl Schmitt postavkom da su svi pojmovi moderne politike sekularizirani pojmovi (kršćanske) teologije (Schmitt 1963: 50; cf. Paić 2013). U suvremenoj umjetnosti pojam ready made označava iskorak u doba potrošačkoga nihilizma. Estetski objekt u radovima Marcela Duchampa preokreće poredak umjetničkih vrijednosti. Umjesto ideje vrijednosti pojam estetske forme nadomješta prijašnji svijet ljepote. Sve postaje formalno čisto i bezbitno. Dodajmo tome još obezboženo i prazno. No u toj igri nadomještanja forme, stvaranje postaje razaranjem. Ništa nije vrijedno postojanosti. Umjesto nepromjenljivosti bitka proces postajanja odlučuje o naravi nove povijesne situacije. Činom pobune protiv ustrojenoga svijeta forme budi se konceptualna mudrost ne-djelovanja.

U posljednjem činu performativne tjelesnosti, kada se sve što jest iskazuje glasnom šutnjom koja odjekuje između ustrašenih i tjeskobnih lica, jezik otvara druge mogućnosti kazivanja. Povratak u stanje infantilne subverzije svih postojećih vrijednosti zahtijeva nekovrsni svijet poremećene filozofske groteske. Ironija pripada sublimnom estetskome objektu poput Duchampova pisoara, a filozofska satira jeziku radikalne volje za isključenjem iz zajednice (cf. Paić 2006a). Zanimljivo je da se upravo 
u Gombrowiczevu shvaćanju umjetnosti s onu stranu aporija avangarde i dekadencije upućuje na figure paradoksa i ironije. To su moćne figure radikalnoga otpora djelovanju nove pošasti utjelovljene u elitizmu i masovnoj kulturi. Jezik se elitizma otvara u apstraktnome stroju iluzija, a jezik mase prožima kulturna industrija idola. U tom formalnome sporu visokoga i masovnoga ukusa uopće se ne radi o različitim mjerilima suđenja. Paradoks je u tome što iz elitizma nastaje obožavanje mediokriteta i Vođe. Iz masovne psihologije rulje ne može nastati ništa drugo doli društveni poredak u kojem Svatko može postati Netko samo pod uvjetom da bude kolektivno ustrojeni Nitko (cf. Newton 1998: 243-260).

Tko govori iz iskustva europskoga raskola? Gombrowicz je doslovno i simbolički napustio vlastitu naciju-državu. Točnije, napuštanjem se odrekao njezine „milosti”. Žrtvovao je sigurnost kolektivnoga identiteta, ono moćno agresivno i ujedno slabo Mi brigom za vlastitu dušu. Postao je čovjekom-bez-domovine. Odlazak jednim bizarnim pukim „slučajem” brodom Trans-Atlantik u Argentinu uoči njemačke zločinačke agresije na Poljsku kojom otpočinje Drugi svjetski rat, za Gombrowicza se pokazalo prekretnom egzistencijalnom odlukom. Nakon raskida s dojučerašnjim svijetom jedini teritorij slobode bio mu je i ostao do smrti poljski jezik (Gombrowicz 2009; cf. Anders 2013). Kada se danas promišlja globalni poredak svijeta iz duha totalne mobilizacije, često se zaboravlja da su emigranti i apatridi 1930-ih godina bili nasilno protjerani iz „svojih” domovina. No slučaj je Gombrowicza jedinstven. Nije bio prognanik nuždom. Postao je slučajem izgnanik. Potom se vlastitim izborom odredio apatridom. To treba posebno istaknuti zbog toga što razlika između ,nužnosti” i ,slučaja" europske imigracije-emigracije u prekomorske zemlje liberalne demokracije, osobito Sjevernu Ameriku i Kanadu, u doba uspona nacizma u Njemačkoj, fašizma u Italiji i istodobne vladavine komunizma u Rusiji predstavlja glavni razlog suvremene raskorijenjenosti svijeta. Kako to valja protumačiti? Jedna od temeljnih postavki Hanne Arendt o budućem svijetu raspada suverenosti nacija-država upozorava da će 21. stoljeće biti dobom imigracije. Sloboda kao bit europske duhovne povijesti određuje stoga razliku spram nomadstva naroda. Apatrid i emigrant nije, dakle, kolektivna priča nekog „Mi” identiteta bez pojedinačnih sudbina. Uvijek je riječ o nesvodljivoj autentičnosti pojedinca. Gombrowicz odlazi u Argentinu kao u „treću zemlju”, o kojoj Franz Kafka u svojem Dnevniku na 
jednom mjestu kaže da je za čovjeka nema. Dakako, iskaz se odnosi na nemogućnost mesijanske nade u obećanu zemlju Kanaan. Sve što preostaje svodi se na neprestano lutanje pustinjom neizmjernom bez cilja i krajnjega smisla (cf. Paić 2014b: 305-353). Razlika svjetova u svojoj okrutnoj kontingenciji pokazuje se tako svojevrsnom drugom „nužnošću”. Apatridima preostaje jezik njihova mišljenja i pjevanja - ta jedina istinska domovina one Europe koja živi u snovima i čežnji za povratkom u izgubljeni zavičaj. U svojem Dnevniku Gombrowicz hladnom preciznošću naglašava da je razlika između njega i njegova prijatelja, avangardističkoga poljskoga književnika i slikara Brune Schulza, kojeg je 1942. godine ustrijelio neki pripadnik Gestapa u židovskome getu Drohobycza, razlika dvaju „svjetova”: „Bruno je bio čovjek koji je zanijekao sebe. Ja sam tragao za sobom. On je žudio uništenje. Ja sam htio ostvarenje. On je bio rođen da bude sužnjem, a ja da budem gospodarom. Bio je židovske rase, a ja iz obitelji poljske vlastele" (Gombrowicz 1988b: 6 [prev. Ž.P.]).

Apatrid nikad ne može postati nomadom. Pomutnja u pojmovima dolazi očito iz brisanja razlike između svjetova moderne Europe i Zapada te drugih svjetskih kultura. Štoviše, bez te razlike uopće nije moguće doprijeti do uvida kako identitet europskoga svijeta ne proizlazi ni iz čega mitskoga, praktičnoga i posebnoga. Bit se europskoga svijeta razotkriva upravo iz mogućnosti slobode pojedinca u njezinim duhovnim formama. Među njima filozofija ima povlašteno mjesto začetka i temelja (arhé) (Gander 1993). Čovjek bez domovine određuje se metapolitičkim subjektom nepripadništva urođenoj naciji-državi. Tome usuprot, nomad je kategorija predmoderne društvene zajednice. Značajka je nomadskih naroda da nemaju svoje stalno mjesto prebivanja. U neprestanoj su potrazi za drugim „domom” kao materijalnim izvorom vlastite egzistencije. Plemena daju znak identiteta nomadskim narodima, a ne odluka autonomnoga pojedinca (Paić 2009: 178-207). Gombrowiczevo je bezdomovinstvo otuda jedna od nužnih posljedica europske političke povijesti 20. stoljeća. To je slučaj povijesne nužnosti raspada ideje suverenosti, a ne patetična gesta aristokratskoga pobunjenika protiv okoštale forme konzervativnoga društva. Da bi uopće moglo doći do takve životne odluke potrebno je europsko iskustvo slobode. Ono se određuje radikalnom egzistencijom u nepripadnosti nikome i ničemu. Nije li to istinska sudbina modernoga intelektualca na rubu Europe? S onu stranu uzaludnoga angažmana i prostituiranja umjetnosti 
u propagandne svrhe ideologije i politike totalitarizma i postdemokracije preostaje otpor u samome jeziku mišljenja (Paić 2006b). Ipak, ono jedino što čini pripadnost neotklonjivom, a Gombrowiczev prethodnik u drugome duhovnome liku bio je irski apatrid i književnik James Joyce, jest neotklonjiva sudbina jezika. U pravu je Martin Heidegger kad kaže da jezik pripada u događaj. Jezik govori, a ne „Ja” i „Mi” (Heidegger 2007). Kroz jezik se uspostavlja mogućnost govora o osobi u modusu pojedinačne univerzalnosti. Ako sam istinski čovjek, u meni diše duhovni lik povijesnoga ljudstva. Od početka do kraja svijeta ista je sudbina osobnosti. Ako to, pak, nisam, svijet je izvitoperen u laži i gadosti.

Odluka o radikalnoj ekscentričnosti u moderno doba morala je biti istodobno paradoksalna i vjerodostojno moralna. Odreći se svega što čini izvanjski lik poljske povijesti u znakovima tog čudovišnoga „Mi”subjekta kao tiranije Drugoga u liku političke moći zajednice nad pojedincem, imalo je za posljedicu posvemašnju isključenost. Biti sam sebi dostatan u jeziku podrijetla koji se ne može izbjeći poput zle kobi, znači biti osuđen na apsurdni luksuz bezdomovinstva na rubu svijeta. Poljska je tako samo zamijenjena „trećom zemljom” dovoljno dalekom od Europe i stoga idealnom za izgnanstvo bez nostalgije za zavičajem. Što preostaje dragovoljno isključenome iz ,velike povijesti” jednoga narativa bez životnosti tijela, bez erosa i spontanosti slobode? A što drugo doli jezik radikalne subverzije forme!? Nema ovdje mjesta tužaljkama za zavičajem. Još manje je smisleno utjecati se melankoliji europske povijesti. Iako je ona pronašla svoje neprispodobive tragove u slikarstvu Albrechta Dürera i Paula Kleea te u filozofskoj esejistici Waltera Benjamina, tajna se melankolije skriva u nemoći suočenja sa sadašnjošću. Zato valja izbjegavati riječ egzil u smislu privremenoga utočišta. Sloboda je egzistencijalna odluka o nepripadanju onome što nas povezuje s korijenima. I tko god bude nastavljao s tlapnjama o povratku na Itaku kao na nikad izgubljeno tlo neke mitske Europe, taj prodaje utopijske priče bez pokrića u zbilji. Misliti Europu danas moguće je očito samo iz iskustva destrukcije jezika. A to znači misliti i pisati iz iskustva bezavičajnosti i raskorijenjenosti, oslobođeni od fame o vječnome identitetu i uzvišenim vrijednostima. S Gombrowiczem smo prisiljeni krenuti u posve drukčijem smjeru. U zagrljaj kaosa i u zemlju erosa, bez napasti da je sve moguće umom obrazložiti. Poput ranokršćanskoga filozofa Tertulijana, ali njemu usuprot, valja od- 
lučno tijelu dati što ga ide: Credo, quia absurdum! Paradoksalno, baš kao što to čini njegov anti-junak u romanu čije ime ne znači ništa određeno, ništa „konkretno” u svijetu, jer Ferdydurke je komična ukronija povratka u stanje zamrznutosti razvitka.

Otkriće tjelesnosti i neukrotivosti slobode protiv stroge discipline uma u uzdizanju do posljednje forme savršenstva u religioznome osjećaju blaženstva za Gombrowicza predstavlja strategiju anti-filozofije imanencije. I doista se može kazati da je u tome prethodnik svih pokreta rastemeljenja metafizike od egzistencijalizma, strukturalizma do poststrukturalizma s Deleuzeom kao vrhuncem korporalnoga obrata Gombrowicz (1988a: 181-185). Put unazad, od uma k tijelu, od mentalnih slika mišljenja do emocija, od uzvišenih sfera do gole materijalnosti znaka, pretpostavlja razračunavanje s počecima europske književne tradicije (cf. Goddard 2010). Utoliko je Gombrowicz parodija i persifliranje Dantea kao kanona metafizike forme. Riječ ukronija upotrijebio je Baudrillard u jednom ogledu o suvremenim tehno-znanostima, patafizici i problemu vremena (Baudrillard 2008). Ukronijsko znači putovanje iz budućnosti u prošlost u zakrivljenome prostoru svemira. Ukratko, kraj ljudskoga vremena pretpostavlja mogućnost ozbiljenja tehno-fikcija kao virtualne aktualizacije događaja. Vrijeme prostoru određuje granice. A to se događa na taj način što se prostor širi i sužava u mogućnosti implozije. Ono čemu se teži nije na višoj razini ,smisla”. To je ono najbliže. Anti-umjetnost u formi stvaralačke destrukcije kao igre shvaća sebe ne-ozbiljno. Postupak je to samodestrukcije i estetskoga obrata avangarde. No sve je drugo autentično i novo zato što se naslanja na daleke prethodnike, a da ih se ne oponaša ni u stilu niti u sceni pisanja - Voltairea i Nietzschea. Jezik ovdje sam sebi određuje duhovne srodnike polazeći od ustrajnosti i dostojanstva slobode pojedinca, a prosvjedujući protiv logike čopora nacije-države-kulture. Apsurd i bizarnost, povratak u stanje ponižene nevinosti puberteta, kako je sam Gombrowicz naslovio svoju prvu knjigu proza Uspomene iz puberteta - eto prave nevolje s anti-filozofijom bezobzirne nevinosti (Gombrowicz 2007).

Isključenost iz svijeta moderne autonomije subjekta označava nešto krajnje paradoksalno. Ideja nacije u novome vijeku još od Bodina upućuje na dvojako samoodređenje čovjeka: 1) kao autonomnoga i slobodnoga pojedinca i 2) kao pripadnika urođene etničke zajednice. Etimologijski, 
riječ nacija upućuje na latinski izraz natio. A to znači ono „u-rođeno”, neslobodno, što dolazi iz slijepe nužnosti prirode u liku prebivanja u okružju statičke političke zajednice. Stoga se moderni čovjek ne određuje više svojim ,prirodnim” podrijetlom. Suverena odluka o nepripadnosti Drugome čini njegovo dostojanstvo. Suverenost je, dakako, kategorija novovjekovnoga prirodnoga prava. Odnosi se na moć prenošenja ovlasti s Boga na čovjeka. Kao predstavnik njegove moći na zemlji suveren može biti: a) vladar u osobi kralja ili cara, b) politički narod u demokratskoj republici i c) autokratski tiranin koji vlada u ime naroda. Europa se u 20. stoljeću nakon iskustva dva svjetska rata, imigracije i progona Židova, fašizma i komunizma, nalazi u stanju postimperijalne suverenosti (Sloterdijk 2002). Živimo u doba kraja nacija-država kakve smo poznavali od razdoblja apsolutnih monarhija do liberalnih demokracija. Promjene u Europi nakon kraja komunizma 1989. godine bile su dvoznačnoga karaktera: s jedne strane nošene vihorom zakašnjele nacionalne emancipacije, a s druge, pak, uklopljene u proces stvaranja globalnoga poretka nove postimperijalne suverenosti. No kada suverenost gubi razlog svoje opstojnosti u svim područjima djelovanja, kako je to pokazao na kraju svojega misaonoga života filozof Jacques Derrida u predavanju povodom dodjele nagrade Walter Benjamin 2001. godine, tada se susrećemo s opasnošću obnove krhotina ove ideje. Ne smije se zaboraviti kako je ona skrivila svjetske ratove unazadivši ideju Europe do obrisa neprepoznatljive budućnosti:

Dekonstrukcija pojma bezuvjetnoga suvereniteta nedvojbeno je nužna i u tijeku, jer je to nasljeđe s mukom sekularizirane teologije. U najvidljivijem slučaju pretendiranoga suvereniteta nacionalnih država, ali i drugdje (jer on se nalazi posvuda, u pojmovima podanika, građanina, slobode, odgovornosti, naroda itd.), vrijednost suvereniteta danas je u punom raspadu (Derrida 2009: 237-270).

Je li time napuštena i spasonosna vizija Europe kao duhovnoga svijeta onoga trojstva moći koje spominje Valéry kada govori o razlici između Europljanina i stanovnika drugih dijelova svijeta? Ostavimo to za zaključno razmatranje. Vratimo se iznova pitanju jezika i egzistencije. 


\section{Okružje duše - Iz daleke blizine}

U sukobu između forme i kaosa postoji još i unutarnja razina djelovanja binarnih opreka. Ona se sastoji u prožimanju jednog s drugime. $\mathrm{Na}$ površini se zbiva ples pod maskama. U dubini grotla sve ključa od vibracija zemlje. Europski duhovni identitet u promišljanju Juliena Bende, a on ovdje nije osamljen slučaj vizionara i utopiste, često se dovodi do krajnjih granica opreke između zahtjeva uma i imperativa srca. Podrijetlo se ovoga spora nalazi još na početku novovjekovne filozofije u Renéa Descartesa. Razlikovanje supstancije uma (res cogitans) i tijela (res extensa) nužno emocije spušta na razinu animalnoga svijeta. Dvojnost svjetova gotovo da je nepomirljivom. Emocionalnost kao da ne pripada tom sklopu ideja za koje se vrijedi boriti, ako ni zbog čega drugoga, onda zbog toga što regulativno potvrđuju vjeru u bolji svijet zasnovan na načelima istine, slobode, pravde i jednakosti neurođenih Europljana. Bez univerzalnosti kategorije europskih građana, a ne etničkih skupina koje se bore u tisućgodišnjim „svetim ratovima” za isključenost Drugih, ne može postojati nimalo nade u budućnost umne tvorbe kozmopolitske zajednice. No kako je moguće da se kaosu pripisuju značajke reda (taxis) i forme? Kaos se u Gombrowiczevu shvaćanju svijeta pojavljuje stvaralačkim načelom stvaranja nove forme. Ako je kaos upravo ono što se od Grka preko Nietzschea shvaća životom i smrću, kružnim kretanjem tijela i duše, jer jedno bez drugoga prestaje biti životnim entitetom, tada se govor o osjećaju ili onome što tradicionalno pripada „logici srca” mora otvoriti u posve drukčijem smjeru. Možda je u pravu Susan Sontag kada Gombrowiczev roman Ferdydurke naziva prvim ničeanskim romanom ideja. Ovdje se podzemna sila života suprotstavlja grobnicama tradicionalnih vrijednosti. Dvojnosti moraju iščeznuti da bi cjelina mogla nadvladati sukob između posebnosti i dijelova. Međutim, ova cjelina nije vertikalna. Ona ne dolazi iz visina onostranosti. Ne katapultira se sa zemlje u nebeske visine kao Kierkegaardova transcendencija apsoluta ili Božje egzistencije. Potrebno je već jednom krenuti „odozdo”. Treba poći od složenosti samoga tijela u svim njegovim sklopovima. Možda baš točno onako kako se to zbiva u pobuni jedne druge mudrosti. A ona ne dolazi više sa Zapada. Ne zavaravajmo se ipak: singularnost djelovanja nije ni u kakvoj opsesiji Istokom. Smjer se mora radikalno preusmjeriti da bi svijet duhovne cjeline bitka 
mogao iznova pokazivati put i Drugima. Je li za tako nešto odavno prošlo vrijeme?

U Dnevniku, kao i u jedinom formalno strogom filozofskome spisu Vodič za filozofiju u 6 sati i 15 minuta, gdje između ostaloga razlaže nauk egzistencijalizma Jean-Paula Sartrea, filozofiju egzistencije Karla Jaspersa i Gabriela Marcela, te lucidno upućuje na veličinu Heideggerova mišljenja bitka unatoč hermetičkome načinu pisanja mislioca s Todtnauberga, nailazimo na prijepor u određenju biti onoga što čini duhovni identitet Europe (Gombrowicz 2004). Je li jezik u svojim najvećim mogućnostima kazivanja kaotične forme egzistencije (čovjeka) moguće svesti na racionalnu strukturu sporazumijevanja? Ovo pitanje nije samo temeljno pitanje suvremene filozofije jezika nakon Wittgensteina i Heideggera. Može se unaprijed reći da je to pitanje presudno za suvremeni prijepor između konstrukcije i dekonstrukcije ideje Europe. S obzirom na sukobe oko geopolitičke i geofilozofske ,sudbine” naroda na rubovima jedne nikad dovršene priče o granicama Carstva, jezik uvijek svjedoči to stanje-između. Naravno, riječ „Carstvo” nije ovdje slučajno spomenuta. Ne koristi se poput nevine metafore za tegobnu konstelaciju odnosa u sadašnjosti. Vidjeli smo da su Paul Valéry, a nakon njega izričito Martin Heidegger 1935. godine, bit Europe sagledali iz političke artikulacije moći. Početak seže u republikanizam Rimskoga Carstva. Odatle se preko ideje moderne Amerike proteže do 20. stoljeća. Tada se u planetarno doba ideja Carstva prevodi (translatio-transductio) u dvije forme totalne mobilizacije liberalizma i komunizma: američki provincijalizam potrošnje i ruski despotizam gole sile (Heidegger 1987).

Ako je jezik strukturirani kaos kazivanja, što čini njegovu bit u određivanju metafizičke sudbine Europe? Iz daleke blizine između Heideggera i Gombrowicza progovara duboka nelagoda. Ona nastaje u razumijevanju jezika kao temeljne strukture egzistencije čovjeka u bezavičajnome svijetu. Sabire se, nadalje, u nemogućnosti ,racionalnoga” dokazivanja onoga što je samome jeziku nedokazivo. Razlog leži u tome što se jezikom u njegovoj „goloj faktičnosti” dokazuje sloboda kao područje onoga neiskazivoga i neizrecivoga. Tko govori o iskustvu destrukcije jezika, govori o granicama iskazivosti mišljenja. Usporedimo li prekretni roman visokoga njemačkoga modernizma s obzirom na pitanje o jeziku kao događaju kazivanja, kao što je primjerice roman Alfreda Döblina Berlin Alexanderplatz 
s Gombrowiczevim Ferdydurke, bit će bjelodanim kako je u oba slučaja riječ o ekspresivnome demontiranju tzv. realnosti poniranjem u ponižene i tamne sfere tjelesnosti. Sve se ,uzvišeno” skrnavi. Riječ ,guzica” u Ferdydurke gotovo da ima polisemijsku funkciju označitelja bez svoga označenoga jer se odnosi na sve ono što se razmeće postojanom i nepodnošljivo beživotnom formom. Svaki se kamen od oniksa nedodirljive tradicije na kojoj su izgrađeni monumentalni spomenici nacionalizma i patriotizma, kako „velikih”, tako i „malih” naroda” Europe, mora razlomiti do zadnjih krhotina. Jedino posvećeno sredstvo tog postupka rastemeljenja, koje se istodobno zbiva u filozofiji i umjetnostima kazivanja (drama, poezija, proza), ostaje jezik. U formi kaotičnoga pisma jezik se rasprostire u svim preobrazbama radikalne ekscentričnosti pojedinca (pamflet, dnevnik, esej, proza, drama). Granice jezika postaju fluidnima. Uostalom, takve su zbiljske granice europskoga duhovnoga kruga. Jedina stvarna granica prolazi između autentičnosti duhovnoga života i njegove lakrdije. Ovo drugo pripada fenomenologiji kiča. Može ga se pronaći u svim područjima života, od društva, politike do kulture. Kič nije estetski pojam, premda se uobičajeno tako razmatra. Radi se o životno-egzistencijalnome fenomenu nihilizma europske povijesti. Kada velike vrijednosti gube svoju auru i postaju znakovi neutentičnosti svijeta života na djelu je ideologija kiča. I sam jezik svjedoči o toj pojavi u stilskim razdobljima prekomjernosti ornamenta. Smrt istinske duhovne forme najavljuje nadolazak ere nadomjeska (cf. Broch 1977). Granice „Carstva” nisu i, doduše, granice jezika kad je riječ o najmračnijem od svih pojmova za suvremenu politiku i kulturu - o ,slavenskoj duši”.

Što je to? Kakva je to fantazma? Kakva razorna fikcija ili misterij da se i danas na kraju epohe nacija-država njihovim prelaskom u mreže postimperijalne suverenosti još uvijek poseže za mračnim iskonskim protuotrovom tzv. Europi uma i sklada? I još se uvijek, premda rijetko i s ne baš suvislim objašnjenjem, u povratku elementarnim osjećajima nastoji pronaći preporod i obnova smisla ideje Europe uopće. Posljednji koji bi tu ,veliku priču” smatrao spasonosnim lijekom protiv apokalipse Europe i Zapada bio bi Gombrowicz. Pa zašto se onda vraćati nečemu što ima prizvuk povijesnoga ressentimenta ruske duhovne geopolitike od Solovjeva do Šestova, od Dostojevskoga do Solženjicina s religioznim mesijanstvom u novome ruhu? Zar je „slavenska duša” samo i jedino svediva na ruski 
pravoslavni misticizam, istočnjačku despociju i velikodržavlje (cf. Besançon 2012)? Ponajprije, potrebno je razdvojiti dva pojma koja se u sklopu „slavenska duša” međusobno uključuju i isključuju. Prvi je vezan uz pojam kulturnoga zemljopisa Istočne Europe. On obuhvaća ideju panslavizma kao protutežu pangermanizmu još od 19. stoljeća. Na različite načine oblikovao se i u političkim ideologijama jugoslavenstva u jugoistočnoj Europi, premda s posve drukčijim kulturnim orijentacijama (katolicizam i pravoslavlje, liberalna demokracija i nacionalistički tradicionalizam). Srodnosti u jezičnome smislu povezuju se otuda sa zajedničkim tendencijama u povijesnome razvitku kultura poput poljske, češke, slovačke, ruske, bjeloruske, ukrajinske, srpske, hrvatske, crnogorske, slovenske, makedonske, bugarske. Lingvističko okružje slavenskih jezika uglavnom je homogeno u etničkome smislu, a u prostornome se može objasniti kao preklapajuća topologijska forma života naroda na istočnim rubovima zapadne Europe. Jezik se topologijski reorganizira nakon prodora i proloma osvajačkih pohoda ,velikih nacija”. Na taj način postaje zaštitnim znakom identiteta slavenskih naroda. Razlog valja potražiti u tome što se u njegovoj „biti” razotkriva čitav stroj povijesnoga sjećanja. Slavensko se, dakle, danas može jedino još razumjeti iz duha europske ,postnacionalne konstelacije”, da se poslužimo izrazom Jürgena Habermasa za odredbu biti suvremene Europe kao projekta nedovršene modernosti (Habermas 1998).

Drugi je pojam ono što nedostaje racionalnome poretku tehno-znanosti i logici europskoga povijesnoga napretka. Govor o duši još od Platonova dijaloga Fedon priziva besmrtnost, neuništivost, nepromjenljivost, jednokratnost. Ali i još nešto. Bez toga bi svijet bio uskraćen iskonske blizine svih bića s otvorenošću bitka. Duša je, naime, kako u grčkome, tako i u slavenskim jezicima, oznaka za disanje (psihé i pneuma) i ogledanje, odražavanje biti u pojavi. Poput prirode (fizis) u materijalnome načinu pojavljivanja (hilé), tako se i duša nalazi u svijetu. Ona pripada svakome biću. Biti duševnim čovjekom istodobno znači biti duhovnom osobom i suosjećajnom spram Drugih u njihovoj patnji i sreći. Disanje i ogledanje u Drugome čini dušu pokretačem događaja. Bezdušnost upućuje na hladnu površinu stvari kojima nedostaje životnost. Udahnuti život predmetima znači smjestiti ih u duhovni svijet ljudske egzistencije. Kada se bezdušnost rasprostire uzduž i poprijeko svega što čini ljudski život dostojnim boravka pod zvijezdama iskrsava najčudovišnija forma odnosa u svijetu 
- ravnodušnost. Ta riječ savršeno svjedoči o praznini ljudskoga srca koje ne osjeća brigu ni za vlastitu dušu niti za dušu Drugoga. Utoliko ravnodušnost nije tek smrt onoga što čini bit etike $u$ doba planetarne tehnike - suosjećanja. Još je čudovišnije to da ravnodušnost sada određuje formu društvene egzistencije čovjeka u narcističkoj kulturi patološki stvorenoga sebstva. Sve ovo valja imati u vidu da ne podlegnemo današnjoj euforiji slavljenja subjekta bez dostojanstva vlastite odgovornosti spram Drugoga. Romantičan prizvuk riječi duša odmah se čini vulgarnim profaniranjem čim se spomene pridjev ,slavenska”. To je nešto praiskonsko i divlje, neokaljano i ujedno djevičanski blago. Gotovo u pravilu njome se priziva rituale djevičanskoga žrtvovanja i skupnu osvetu. Čudesan stroj ambivalencije ostaje pritom određen stereotipima pitomoga-divljega Drugoga, egzotične divljine koja se nikad ne može pokoriti racionalnim sredstvima naprosto zato što se ono slavensko određuje negacijom romanskoga i germanskoga, a ne autonomno iz vlastite kulturne projekcije svijeta koji, kao što bi rekao Jacques Derrida, treba doći (l'arrivé) (Derrida 1979).

Razlike između duha i duše bjelodane su i kad nije posrijedi tvrda dvojnost kategorijalnoga ranga. Povijest otpočinje s duhom naroda. Filozofijom se u Grka naziva misterij događaja početka zapadnjačke povijesti. U svojim predavanjima o biti duhovne Europe u doba planetarne tehnike kao krize povijesnoga ljudstva, Jan Patočka, češki filozof i disident u totalitarnome poretku komunizma, otvara problem početka i kraja povijesne avanture europskoga obzorja razumijevanja. Što je Europa? Na to pitanje ne može se odgovoriti posezanjem ni za mitskim govorom osjećaja niti svođenjem mišljenja na znanstvenu kalkulaciju predmetnosti u svijetu. Bit se onoga što čini europsku veličinu univerzalnosti naspram svih drugih misaonih formi ne-europskih naroda nalazi u odnosu razlike između duha ( $\operatorname{logosa}$ ) i duše (psyhé). Patočkin pojam brige za dušu na uistinu autentičan način povezuje ono racionalno i ono emocionalno, ono etičko i ono estetsko, ono što je natpovijesno i povijesno (Patočka 2002). Duša se za Platona može misliti samo iz njezine besmrtnosti. A ono što nazivamo duhom pripada carstvu univerzalnih pojmova. Ideje su upravo takve nadvremenske forme. Iskazuju se matematičkim simbolima u geometrijskome redu kojim se predočava svijet. Nitko nikad nije ovu Platonovu sliku mišljenja razvio do savršenstva kao što je to učinio Spinoza u svojoj Etici. Uglavnom, brigom za dušu uspostavlja se duhovna sveza, životno dostojanstvo ljudske 
egzistencije, jer odanost slobodi nije tek odanost načelima vječne prirode uma, nego ponajprije idejama istine, dobra, pravednosti i ljepote. Dušom se, dakle, u 20. stoljeću filozofijski nisu bavili tek preobraćeni religiozni fundamentalisti. Posve suprotno, promišljanje onoga što dušu čini glavnim pokretačem događanja na rubovima povijesnoga prizorišta nužno nas vraća ishodišnim pitanjima ideje Europe. S onu stranu njezine geopolitičke podjele na Zapad i Istok možda još postoji otvorenost drukčijega smjera mišljenja. Oživjeti brigu za dušu znači otuda radikalno raskrstiti sa svim pogubnim misticizmima barbarogenija s Istoka u liku militantnih preobraćenika i moralista.

Kao što se govor o autentičnoj „slavenskoj duši” čini besmislicom ne odveć toliko stranome svakom pozivu za „duhovnom obnovom" u moderno doba poput uskrsnuća mitova o germanskoj rasi gospodara, ruskome slavofilstvu u savezu pravoslavlja (ikone) i carizma (sjekire), raznim pseudo-sagama o vladavini duha iskonske snage protiv prosvjetiteljske europske utopije o vječnome razumu i miru, tako se ujedno ne može poreći da je problem o kojem ovdje govorimo u nečem drugome. Briga za dušu nužno se mora očitovati kao briga za jezik u njegovoj slobodi. Ali ta sloboda ne može zauvijek biti određena negativno kao sloboda od prisile ili sloboda od slijepe nužnosti. Umjesto negativne pozitivnosti ili pozitivne negativnosti stvar se očito može razriješiti drukčijim shvaćanjem onoga što čini bit ideje Europe. Ako to nije ,krv i tlo” Zapada ni Istoka, dakle zemljopisna neodređenost granica između Atlantika i Urala, onda se odgovor nalazi u ponovnom promišljanju izvora europstva kao duhovne sudbine. Slavenofilstvo je onoliko romantična i mitska farsa o iskonskome „duhu” sklopa kultura i konfiguracije bliskih i različitih naroda da se u 20. stoljeću pokazalo gotovo u pravilu uzaludnim naporom jedne unaprijed beskorisne utopije. Ima nešto fatalno u tlapnjama o autentičnosti iskona, u toj opsjednutosti arhaičnim i mesijanskim krugom povijesne mahnitosti. Tome nije na stanovit način podlegao ni hrvatski književnik Miroslav Krleža. Njegova nikad dovršena drama-esej-fikcija o biskupu Jurju Križaniću, misionaru i slavenofilu koji poput heretika i naivnoga utopista sanja o bratstvu i zajednici naroda u novoj ekumeni kršćanstva protiv povijesnoga raskola na rimski katolicizam i rusko pravoslavlje, kako je to dao naslutiti u raznim bilješkama i dnevničkim zapisima, alegorijski se odnosila na vrijeme destrukcije Europe „sada” i „ovdje”. Pisao je svojega Križanića u ozračju 
strahovlade ustaškoga poretka 1942. godine, u sjeni deportacije Srba, Židova, Roma i komunista u koncentracijske logore, među inima i u stravični Jasenovac (Krleža 2002).

Nije nipošto slučajno, a nije ni paradoksalno, da se govor o „drugoj Europi”, onoj u znakovima vlastite nemoći i svojevrsne žrtvene uloge između Zapada i Rusije, pronalazi u utopijskome zasnivanju jedne kulturne fantazme. Ona je utoliko više realnom ukoliko je manje simboličkom. Što bi to trebalo značiti? Realne fantazme su prema Jacquesu Lacanu svagda postojeće u rascijepu između traumatskoga Realnoga i onoga što čini sublimno polje djelovanja „Velikoga Drugoga” (Lacan 1990). Ako se jezik strukturira kao ono (kolektivno) nesvjesno, možda je moguće na tom tragu otvoriti problem na sljedeći način. Prostori u zemljopisnoj neodređenosti fiksnih političkih granica, kao što je to upravo slučaj Europe između Atlantika i Urala, nužno postaju ideologijske tvorevine kada se radi o borbi za realnu moć u svijetu. Tek se tada ono što pripada strukturi kolektivnoga duhovnoga sklopa, ne više naroda, već zajedničke sudbine srodnih kultura, pronalazi u ,pobratimstvu lica u svemiru”, kako pjeva hrvatski pjesnik Tin Ujević. Riječ je, naravno, o jeziku kao egzistencijalnoj otvorenosti otpora političkoj vladavini središta nad rubom. Nije teško otuda objasniti kako se svaki otpor koji politički završava ratnim porazom naroda s ruba Europe nadomještava kulturnom frustracijom i kompenzacijom za provincijalni položaj. Jezik preuzima u svojem povlačenju iz političke mobilizacije metafizički ton sumorne psihologije ressentimenta. Već je o tome u svojim fragmentima ostavio zapise Friedrich Nietzsche govoreći o Europi kao o pitanju prevrednovanja (moralnih) vrijednosti. U početnim rečenicama svoje interpretacije Nietzscheova mišljenja Heidegger u obrazloženju pojma europskoga nihilizma upućuje na njegovo moderno izvorište u ruskoj književnosti i osobito u Dostojevskoga s poznatom postavkom: „Ako nema Boga, sve je dopušteno" (Heidegger 1998).

Govor o „slavenskoj duši” u formi radikalne kritike dvaju vladajućih diskursa o Europi poprima obrise duhovnoga egzila. I kao što Gilles Deleuze kaže da je paradoksalna sudbina nomada da se on ne kreće, jer je prostor njegova djelovanja topologijski prazan, tako se isto može reći i za dvije vrste radikalnoga i subverzivnoga obrata ideje o biti Europe. Gombrowiczev je egzil i bezdomovinstvo nužan izbor vlastite ekscentrične slobode bez kompromisa sa svijetom. Druga je putanja bijega moralno 
kompromitirana samim činom pristanka suradnje s ideologijsko-političkim poretkom komunizma. Zato se duhovni svijet slobode pojedinca, kao u slučaju Krleže za vrijeme ustaškoga fašističkoga poretka i Titove komunističke vladavine, može nazvati svezom unutarnjega disidenta i skeptičkoga mandarina kraja povijesti. Disidentu je na raspolaganju žustrina srdžbe protiv poretka ogrezloga u zlu bez ikakve ideologije opravdanja osim vjere u nadmoćnu rasu-naciju-kulturu. Mandarin živi u razmaku od vlastitih moralnih promašaja. Nadživljava ga djelo, srozava ga odluka poklonstva pod zlatne skute diktature. Sukob između savjesti i ne-djelovanja trajno obilježava intelektualce u totalitarnim poretcima. Egzil doista više zavarava negoli razotkriva. Biti pisac u egzilu može značiti samo ovo: biti dovoljno daleko od urlika mase i još dalje od zahtjeva forme nacije-države s njezinim konzervativnim institucijama kulture. Ono što je, međutim, ovdje pravim izazovom upravo je u nemogućnosti odredbe bilo čega ,pozitivnoga" kad je riječ o diskursu alternativne kritike Europe iz obzorja čiste ,slavenske duše”. Ipak, nešto u svemu tome ostaje još uvijek zagonetkom. Najbolje je to formulirao Gombrowicz u Posmrtnoj autobiografiji:

Što je Poljska? To je zemlja između Istoka i Zapada, gdje Europa već prestaje postojati, prijelazna zemlja, gdje se Istok i Zapad uzajamno oslabljuju. Kroz to i zemlja oslabljene forme... Nijedan od velikih potresa europske kulture nije doista preorao Poljsku, ni renesansa, ni vjerske borbe, ni Francuska revolucija, niti industrijska revolucija; ovamo su dopirali samo ublaženi odjeci. (...) Katolicizam? Zemlja je doista u orbiti Rima, ali poljski je katolicizam pasivan, temelji se na strogom pridržavanju katekizma, nikada nije bio stvaralačka suradnja s Crkvom (...). Poljski pisci moga naraštaja općenito su mogli birati između dva puta. Mogli su se ograničiti na poljski teren, ali su tada bili osuđeni na podređenost, ili su mogli aspirirati na europstvo, ali su u tom slučaju bili osuđeni na podređenost, jer je to bilo europstvo iz druge ruke, koje je jedino nastojalo stati uz bok Europi i ponavljati Europu (Gombrowicz 2014: 109).

Sve što je ovdje rečeno ima univerzalni karakter fatalnosti. Ali ne pogađa samo „male narode” i njihove mitske projekcije o veličini unutar vlastita jezika koje ne prepoznaje „svijet”. Brutalna je istina navedenoga iskaza u ovome: osuda na ,genijalnost” vlastita puta neizbježno vodi u izolaciju od europskoga duhovnoga obzorja. Tko se autistički sklanja u vlastiti oklop od napuhanoga tradicionalizma, nužno stvara frustraciju i agresiju mediokriteta. Ali tko snobovski oponaša već odavno nevjerodostojni put tzv. Europe i njezine kulture, osjeća se poput pokorne posluge 
u zabačenom provincijskome hotelu. Gombrowicz, doduše, govori o poljskoj književnosti i njezinim zabludama o identitetu. Ali zar na gotovo isti način ne govori i Thomas Bernhard o austrijskome slučaju „trećega puta” koji se nakon poraza nacizma pretvorio u zlokobni savez s katolicizmom i tako proizveo fenomen provincijalne „konzervativne revolucije” $\mathrm{s}$ dalekosežnim posljedicama za europski duhovni identitet (cf. Paić 2014a: 383-420)? Nema sumnje da je ono što nazivamo „kulturom” tek nadomjestak za istinski duhovni svijet. To je ustrojeni pogon institucionalne mašinerije. Nerijetko ona sve više služi izvanjskim svrhama, od ideologije do tržišta, a sve manje ima ikakve veze s jezikom mišljenja i umjetnosti. Uostalom, u svim se Gombrowiczevim tekstovima, a ponajviše u Dnevni$k u$, preobrazba duha umjetnosti u zloduh kulture prokazuje kao pobjeda ignorancije i diktature forme. Isto vrijedi i bez obzira s kojim se znakovljem kultura kitila u ceremonijalne svrhe neke druge još brutalnije moći negoli što je to nacionalizam i njemu prirasli poretci političke servilnosti.

\section{Ravnodušna gordost, ipak na kraju...}

Što onda još preostaje od te proklete ,slavenske duše"? Sentimentalno putovanje u mračne jazbine jezika? Razotkriće novoga europskoga duhovnoga jedinstva na rubu jednog svijeta u krizi? Priznajmo, mnogi su pisci visokoga modernizma, a Gombrowicz je očigledno paradigmatski slučaj zbog svojeg radikalno-subverzivnoga stava protiv svake idolatrije tradicije i hvalospjeva „malih naroda” iz duha njihove umjetnosti, bili dvostruki agenti-provokatori našeg nimalo utješnoga doba planetarnoga nihilizma. Ako već nisu igrali uloge mesijanskih proroka novoga doba nacije-kulture nakon strahota totalitarne ideologije komunizma u Rusiji poput Aleksandra Solženjicina, onda su bili na ovaj ili onaj način upregnuti u jaram nacionalne kulture. Današnja Europa utvara da je kultura njezina bit postojanja, pa je stoga njezina odanost tržištu opsjena maska ispod koje se ne skriva nikakvo drugo lice. Sve je brutalno jasno i providno. Ono što Zygmunt Bauman kaže za obrat iz modernoga u postmodernoga intelektualca očito vrijedi i za položaj kulture u procijepu Zapada i Istoka. Zakonodavci (jezika) bili su univerzalni proroci i moralisti bez vidljivih rezultata. Njima pripada povijest. Tumači (Zakona) danas su umnoženi partikularisti koji 
medijski sudjeluju u proizvodnji diskursa u javnome dijalogu (Bauman 1989: 1247-1249). Što je više emocija u javnoj raspravi u kojoj načelno sudjeluju intelektualci kao pisci i njihova interaktivna publika, to je javni razum poprištem truloga kompromisa između dvaju podjednako loših rješenja ove aporije. Prvi je izolacija u vlastito dvorište nacionalne priče, a druga oponašenje šireg europskoga konteksta kao proširenoga nacionalizma s ljudskim licem. Gombrowicz je odličan primjer intelektualca koji u svojem djelovanju zrcali vrline univerzalnoga zakonodavca novoga jezika i partikularnoga tumača Zakona bez postojećega kanona.

Prva je pretpostavka govora o „slavenskoj duši”, dakle, da tako nešto uopće ne postoji. Ako postoji, onda je sablast bez identiteta. Na nju više nitko ne može staviti svoj žig, a posebno ne oni fundamentalisti sa svojim krvavim pohvalama iskonu. U Gombrowiczevu „korporalnome obratu" skrnavljenje uzvišenih veličina poljske nacionalne povijesti samo je predložak za destrukciju jednoga univerzalnoga jezika besmisla koji se uspostavio kroz metafiziku privida. U tom pogledu doista je Nietzscheova dijagnoza europskoga nihilizma recept za filozofiju i umjetnost visokoga modernizma. Povratak poniženome tijelu u njegovu „svetome” pravu na nevinost i mahnitost zahtijeva rušenje svih zavjetovanih službenika forme: „Oh! Smrtno sam zaljubljen u tijelo! Tijelo je za mene gotovo odlučujuće. Nijedan duh neće iskupiti tjelesnu ružnoću i fizički neprivlačan čovjek za mene će uvijek spadati u nakaze, pa makar bio i sam Sokrat!... Ah, kako ja trebam to posvećenje kroz tijelo! (...) Moja metafizika postoji zato da bi se kotrljala u tijelo" (Gombrowicz 2014: 309).

Druga se pretpostavka govora o „slavenskoj duši” otvara iz pitanja o granicama iskazivosti jezika u njegovoj djelotvornosti suosjećanja s Drugime. Etička perspektiva ovdje nije moralizam. Daleko od toga. Vidjeli smo da svaki moralizam vodi do uzurpacije prava na razliku, pa tako i onaj koji kao u Bendinome slučaju zahtijeva „sveti” francuski jezik za univerzalnost mišljenja u okrilju nadnacionalne Europe. Što je to uopće kraljevstvo emocije u sumornome jeziku slavenstva doli ta avangardna, radikalna i subverzivna gesta rušenja svih čvrstih vrijednosti od koje je satkana povijest beščašća moderne Europe? Zašto danas kada govorimo o krizi Europe i njezinih duhovnih orijentacija, a sve je to u stvari otpočelo nakon dolaska fašizma na vlast 1933. godine, moramo učiniti isto ono što je u ideji htjela europska povijesna avangarda, ali u posve drukčijem smjeru? 
Ne zaboravimo da su svi prekretni prilozi mišljenju ideje Europe u filozofijskome, političkome i estetskome smislu napisani i izgovoreni 1930ih godina: Bendini Govori europskoj naciji, Ortega y Gassetovi tekstovi protiv masovne histerije kolektivnih ideologija, Husserlov govor u Beču 1935. godine kao najznačajniji filozofijski pristup krizi ideje europskoga duhovnoga ljudstva, napokon i Krležin predskazujući ogled „Europa danas" iz 1933. godine.

U ovom razmatranju o jednoj fantazmi s političkim i kulturnim izvorima pisac Witold Gombrowicz nije izabran da bude nesvodljivim svjedokom sumnje u svrsishodnost obnove moći jezika kao jezgre duhovnoga svijeta koji možda dolazi u drugome liku od onoga koji nam se činio svagda primjerenim. Govor o duhovnim temeljima Europe mora, dakle, proći kroz laboratorij kaosa. Povratak tijelu ne znači otuda veličanje morbidnih $\mathrm{i}$ atavističkih obreda poniženih nacija s ruba i njihova ressentimenta. Posve suprotno, upravo je Gombrowicz pravi ,poljski” pisac jer je znao „kreativno mrziti svoju domovinu”, kako pojam domoljuba definira Pursewarden, amblematski lik iz četverodjelnoga romana Lawrencea Durrella Aleksandrijski kvartet. Odlika je autentičnoga „domoljuba” u njegovoj avangardističkoj egzistenciji na rubu svijeta, u egzilu i emigraciji, da bude dostojan vlastite slobode kao vjere u ovaj, jedini svijet. Ne treba tražiti drugu Europu tamo gdje je nikad nije bilo. Jer ona nije ukorijenjena u „krvi i tlu", u formi političko-religioznih institucija nijekanja života. Njezino je mjesto u umu i srcu jednog te istoga tijela. A njemu konačno treba vratiti izgubljeno i žrtvovano dostojanstvo. Nije li vrijeme da se duhovni temelji Europe, možda baš polazeći od tragova Gombrowicza, pronađu u imanenciji radikalne i subverzivne tjelesnosti? To je nešto mnogo uzvišenije od bauljanja po močvarama i podzemlju neke odavno propale ,velike priče” o političkome i kulturnome slavenofilstvu, gdje umjesto Platona i matematike pršti krv, sperma i suze onih žrtvovanih na rubu svijeta u ime cezaropapizma s katoličkim ili pravoslavnim križem. Emocije nisu protuotrov hladnome razumu Zapada. One su samo i jedino ono što može biti drukčije i jest Drugo od zatočeništva duha u čistoj formi. Što preostaje jest životnost posve drukčijega života duha koji otpočinje svoj drugi početak s mišlju da je svaka etika žrtvovanja rođen iz ravnodušnosti spram Drugoga. Gombrowicz o tome uvjerljivo zbori: „Zahvalan sam Najvišemu što me izvukao iz Poljske, kada se moja književna situacija počela poboljšavati, 
i prebacio na američko tlo, u strani jezik, u samoću, u svježinu anonimnosti, u zemlju bogatiju kravama nego umjetnošću. Led ravnodušnosti tako dobro konzervira gordost" (Gombrowicz 2014: 314).

U dubini duše naš se sumorni jezik smije svim našim vjerodostojnim zabludama. Bez njih bismo ostali zauvijek zaleđeni u svojoj blaženoj nevinosti. Europa je danas na pola puta prolaza kroz mračnu šumu. A u daljini se ne nazire ništa drugo osim to posvuda isto, ali različito, zasljepljujuće zelenilo.

\section{Literatura}

Anders J., 2013, From the Stacks: 'Unsentimental Journey', „New Republic”, $<$ http://www.newrepublic.com/article/114017/jaroslaw-anders-reviews-witold-gombrowiczs-trans-atlantyck>, 26.07.2014.

Baudrillard J., 2008, The Perfect Crime, London-New York.

Bauman Z., 1989, Legislators and Interpreters. On Modernity, Postmodernity, and Intellectuals, „American Journal of Sociology” br. 5, god. 94, str. 1247-1249.

Benda J., 1933/1993, Discours a la nation européene, Paris.

Benjamin W., 1991, Gesammelte Schriften, sv. 7, Frankfurt/M.

Besançon A., 2012, Sainte Russie, Paris.

Broch H., 1977, Geist und Zeitgeist. Essays zur Kultur der Moderne, Frankfurt/M.

Cioran E., 2011a, Dvije vrste društava, prev. V. Popović, C. Noica, „Tvrđa” br. 1-2, str. $147-156$.

Cioran E., 2011b, Odgovor dalekog prijatelja, prev. L.I. Frana, „Tvrđa” br. 1-2, str. $157-165$.

Derrida J., 1979, L'écriture et la différence, Paris.

Derrida J., 2009, Sveučilište bez uvjeta, prev. G. Vujasninović, „Europski glasnik” br. 14, str. 237-270.

Gander H.H., (ur.), 1993, Europa und die Philosophie (Martin Heidegger-Gesellschaft - Schriftenreihe, sv. 2, Frankfurt/M.

Goddard M., 2010, Gombrowicz, Polish Modernism, and the Subversion of Form, Indiana.

Gombrowicz W., 1981, Ferdydurke, prev. U. Radnović, Beograd.

Gombrowicz W., 1988a, Diary, sv. 1, 1953-1956, Evanston.

Gombrowicz W., 1988b, Diary, sv. 3, 1961-1966, Evanston.

Gombrowicz W., 2004, A Guide to Philosophy in Six Hours and Fifteen Minutes, New Haven-London.

Gombrowicz W., 2007, Bakakaj, prev. T. Miletić-Oručević, Zaprešić.

Gombrowicz W., 2009, Trans-Atlantik, prev. M. Martić, Zaprešić.

Gombrowicz W., 2014, Posmrtna autobiografija, prev. M. Martić, Zaprešić. 
Habermas J., 1998, Die postnationale Konstellation: Politische Essays, Frankfurt/M.

Heidegger M., 1987, Einführung in der Metaphysik, Tübingen.

Heidegger M., 1998, Nietzsche, sv. 1-2, Stuttgart.

Heidegger M., 2007, Unterwegs zur Sprache, Stuttgart.

Kowalska M., 2010, I is another/Je est un autre. Gombrowicz and the Polish Question, „Intertext”, <http://intertekst.pl/215_artykul.html?jezyk=en>, 26.07.2014.

Krleža M., 2002, Pogovor za dvije drame: Areteja i Jurja Križanića, Zagreb.

Lacan J., 1990, Le Séminaire, sv. 11, Les Quatre Concepts fondamentaux de la psychoanalyse, Seuil.

Müller J.W., 2006, Julien Benda's Anti-Passionate Europe, „European Journal of Political Theory" br. 2, god. 5, str. 125-137.

Newton A.Z., 1998, „, Nothing But Face” - „To Hell with Philosophy”? Witold Gombrowicz, Bruno Schulz and the Scandal of Human Countenance, „Style” br. 2, god. 32, str. 243-260.

Paić Ž., 2006a, Moć nepokornostI: Intelektualac i biopolitika, Zagreb.

Paić Ž., 2006b, Slika bez svijeta: Ikonoklazam suvremene umjetnosti, Zagreb.

Paić Ž., 2009, Zemljovidi za lutalice: nomadizam i kaos kraja povijesti, u: Ž. Paić, Zaokret, Zagreb, str. 178-207.

Paić Ž, 2013, Sloboda bez moći: Politika u mreži entropije, Zagreb.

Paić Ž., 2014a, Morbidna arkadija: Thomas Bernhard i uzvišeni stroj jezika, u: Ž. Paić, Tré́a zemlja: Tehnosfera i umjetnost, Zagreb, str. 383-420.

Paić Ž., 2014b, Osmijeh mrtve nevjeste: Franz Kafka i neljudsko, u: Ž. Paić, Treća zemlja: Tehnosfera i umjetnost, Zagreb, str. 305-353.

Patočka J., 2002, Plato and Europe, Stanford - California.

Schmitt C., 1963, Der Begriff des Politischen, Berlin.

Sloterdijk P., 2002, Falls Europa erwacht: Gedanken zum Program einer Weltmacht am Ende des Zeitalters ihrer politscher Absence, Frankfurt/M.

Sontag S., 2002, Gombrowicz's Ferdydurke, u: S. Sontag, Where the Stress Falls, London, str. 97-105.

Valéry P., 2000, La crise de l'esprit, Paris. 
